\title{
SOSYAL ADALET KAVRAMININ BAZI TEMEL HAKLAR İLE CEZA VE VERGİ ADALETINE ETKILERİ
}

\author{
Mehmet Ali ZENGIN*
}

\section{$\ddot{O} Z$}

Sosyal adalet kavramı bazı temel haklar bakımından önemli etkilere sahiptir. Bu kapsamda çalışmamızda çocuk hakları, sağlık hakkl, çevre hakkı ve cinsiyete bağlı ayrımcılık yasağı ele alınırken güncel tartışmalara ve görüşlere yer verilmiştir. Sosyal adalet konusu çok sayıda temel hak bakımından ele alınabilir. Ancak konu iki gerekçeyle bazı temel haklarla sinırlandırllmıştır. Çocuk hakları ve cinsiyete dayalı ayrım yasağının tercih edilmesinde, ortaya çıkan sorunların toplumun büyük bir kesimini ilgilendirmesi ve bu alanlarda sosyal adaletin sağlanmasına duyulan ihtiyacın boyutu etkili olmuştur. Yine sağlık hakkı ve çevre hakkının tercih edilmesinde, güncel gelişmelerin varlığı ve sosyal adalet açısından bu hakların yeni yeni tartışılıyor olmasl etkili olmuştur. Öte yandan vergi ve ceza konusundaki hukuki düzenlemelerin sosyal adalet ihtiyacını tatmin edecek şekilde tesis edilebilmeleri beklentisi, konunun bu alanlar bakımından ele alınmasında etkili olmuştur. Vergi ve ceza alanına dair hukuk kuralları tesis edilirken, sosyal adaletin sağlanması da önemli bir hedeftir. Ceza adaleti ve vergi adaleti, sosyal adaletin sağlanmasında önemli ve olumlu bir etki meydana getirmektedir.

Anahtar Kelimeler: Sosyal Adalet, Insan Haklarl, Vergi Adaleti, Ceza Adaleti Ayrimcilık.

\section{EFFECTS OF SOCIAL JUSTICE CONCEPT ON SOME BASIC RIGHTS WITH TAXATIONAL AND CRIMINAL JUSTICE}

\section{ABSTRACT}

Social justice concept has important effects in terms of some basic rights. Actual discussions and thoughts about children rights, right to environment, right to health and prohibition of gender discrimination are addressed in our study with in this context. Social justice concept can be considered with regard to plenty of basic rights. However, topic was limited with some basic rights in the light of two reasons. Election of children rights and prohibition of gender discrimination base on two considerations; one is largeness of problems effect major part of society, another one

\footnotetext{
Doç. Dr., Ankara Yıldırım Beyazıt Üniversitesi Hukuk Fakültesi Anayasa Hukuku Anabilim Dalı Öğretim Üyesi, e-posta: mazengin@ybu.edu.tr

ORCID: 0000-0003-1263-5102

DOI: $10.34246 /$ ahbvuhfd.637943

Yayın Kuruluna Ulaştığı Tarih : 15/04/2019

Yayınlanmasının Uygun Görüldüğü Tarih: 17/10/2019
} 
is size of social justice necessity. Nevertheless, actual advances and new discussions about social justice are the main reasons of election of right to health and right to environment. On the other hand, regulating taxational and criminal rules in the aim of expectation of judicial satisfaction needs effected election of the topic. Reach to social justice has got crucial target, when regulating criminal and taxational norms. Criminal and taxational justice have important and positive impact on achieving social justice.

Key Words: Social Justice, Human Rights, Taxational Justice, Criminal Justice, Discrimination.

\section{GİRIŞ}

Sosyal adalet ve hukuk arasındaki ilişki adaletin sadece yargısal olmadığını, bu bakımdan siyaseten de adaletin tesisinin gerekli olduğunu ortaya koymaktadır. Buna göre sadece hukuk kurumlarının değil siyaset kurumunun da adaletin dağıtıcısı olduğu söylenebilir. Hukuk, sosyal adaletin tesisinde önemli bir araç olarak görülebilir. Zira hukuki düzenlemeler, en azından neticeleri yani toplumda ortaya çıkarttıkları sonuçlar bakımından, sosyal adaletin sağlanmasına aracılık etmektedirler. Ancak hukukun uygulayıcısı olan yargının, sosyal adaletin sağlanmasına doğrudan bir etkisi bulunmamaktadır. $\mathrm{Bu}$ nedenle sosyal adalet kavramı daha ziyade siyasetin konu alanına girmektedir. Bununla birlikte son dönemlerde siyaset kurumunun bu konudaki eksikliklerinin hukuk ya da yarg1 yoluyla giderilip giderilmeyeceği üzerine fikirler ileri sürülmektedir. Yargının adaleti sağlama görevi özellikle insan hakları ihlalleri bakımından düşünülecek olursa, siyaset ve hukuk arasında gri bir alan oluşturmaktadır. Sosyal haklar bakımından siyaset kurumunun ihmal ya da ihlal edici davranışları anayasa yargısı bakımından dava ya da başvuru konusu edilebilmektedir. Örneğin, sağlık hizmetinden eşit olarak yararlanamayan bir bireyin sağlık hakkının ihlaline dayalı olarak bireysel başvuruda bulunacak olması durumunda yargının vereceği karar aynı zamanda sosyal adaletin sağlanmasında da önemli bir rol oynayacaktır. Bu noktada siyaset kurumunda çözüm bulamayan bireyler hukuki mekanizmalara yöneleceklerdir. Öte yandan hukuk kurallarının çoğu, gerekçe olarak sosyolojik gerçeklere dayanmaktadır. Toplumdaki farklılıklar arasında adaleti sağlamanın gereklerinden bir tanesi de sosyolojik gerçeklerin farkında olabilmekten geçmektedir. Sosyolojik gerçeklerin göz ardı edilmesi 
suretiyle ne kuralların icracısı konumundaki yargının ne de bu kuralların içerik ve kapsamlarını tayin edecek olan parlamentoların tam olarak adaleti tesis edebilmeleri mümkün görünmemektedir. Netice olarak sosyal adaletin, insan hakları marifetiyle ve anayasa yargısı yoluyla gerçekleştirilmesi düşüncesi, çalışmamızda da ortaya konulduğu gibi sosyal adalet ve hukuk arasındaki bağlantının incelenmesini gerektirmektedir. $\mathrm{Bu}$ bağlantının doğru tespit edilmesi, toplumda ortaya çıkan sapmaların ya da dengesizliklerin önüne geçilmesinde önemli bir rol oynayacaktır. Öte yandan anayasa yargısına ya da mahkemelerine sosyal adaletin insan hakları yoluyla tesisi gibi bir görevin yüklenecek olması mahkemelerin "aktivist" tutumlar sergilemelerine kapı aralayabilecek bir zemin de oluşturabilir.

\section{SOSYAL ADALET KAVRAMI}

Sosyal adalet kavramı, genel olarak ahlak ve siyaset alanında kullanılmaktadır. Ancak kavramın belirsizliği ve kulağa hoş gelen bir yapıda olması pek çok kişinin pek çok alanda bu kelimeyi kullanmasına yol açmaktır. Bununla birlikte kavramın açık ve belirgin bir şekilde tanımlamasının yapılmasına dair önemli bir adım atılmadığı görülmektedir. ${ }^{1}$ Buna göre "sosyal adalet" kavramı genel olarak ne anayasalarda belirlenmiş ne de anayasalarda yer alan ilkelerin kapsamında tanımlanmış değildir. Bu durumda kavramın doktrindeki görüşler çerçevesinde mi yoksa yargıçların anayasadan mülhem yorumlarına göre mi belirlilik kazanacağı gündeme gelmektedir. Bu nedenle anayasanın yorumu yanı sıra moral değerlerden yargısal değerler üretmeye kadar farklı etkiler sosyal adaletin belirlenmesinde etkili olmaktadır. ${ }^{2}$ Bununla birlikte sosyal adaletin yöneldiği ve düzenleme alanı içerisine giren hedefler, ekonomi, işsizlikle mücadele, toprak edinme hakkı, kadınlar için iş bulmada firsat eşitliği, ayrımcılıkla mücadele, ortaklıkların daha etkin bir şekilde düzenlenmesi, vergi siteminde çeşitlendirme ve daha adil bir eğitim sistemi olarak ifade edilmektedir. ${ }^{3}$ Buna göre sosyal sorumluluklar varlığını devam ettirebilecek seviyeye gelene kadar sosyal adalet ilerleyişine devam edeceği dile getirilmektedir. ${ }^{4}$ Sosyal adalet teorisine hem insani hem de pragmatik

1 NOVAK, Michael, What is Social Justice, Capital University Law Review, C.21, s. 877.

2 BEDAU, Hugo Adam, The Death Penalty: Social Policy and Social Justice, Arizona State Law Journal, 1977, s. 769.

3 BRAITHWAITE, John, Restorative Justice and Social Justice, Saskatchewan Law Review, C.63, s.186.

4 GOTTLIEB, Henry M., Legal Rights and Social Justice, University of Detroit Law Journal, C.2, s.34. 
açıdan özellikle de güvenlik bakımından ihtiyaç duyulmaktadır. Bu notada yanlış belirlenecek teoriler faydadan çok zarara sebep olacaktır. ${ }^{5}$

Öte yandan sosyal adalet toplumdaki değer çeşitliliği kapsamında genel bir iyiye ya da genel bir adalet anlayışına indirgenemez. Refahın sağlanmasında kullanılacak kaynaklar yetersiz olup bireylerin ihtiyaçları ve bunların seviyeleri oldukça farklılık arz etmektedir. $\mathrm{Bu}$ nedenle ekonomik eşitsizliklerin giderilmesi yoluyla genel bir iyiye ulaşılamayacağı ileri sürülmektedir. Bu durumda da sosyal adalet, bu hedefin ötesinde, kaynaklara erişim bakımından haklar ve fırsatlar bakımından adil ve eşit olunmasını gerektirmektedir. $^{6}$

Sosyal adalet kavramı toplumun pratiklerini ve kurumlarını oluşturma ve toplumda üretilen fayda ve yüklerin; haklar, engeller, avantajlar, dezavantajlar, fırsat eşitliği ve eşitsizliği, zenginlik ve yoksulluk bakımlarından dağıtımı ile ilgili olarak düşünülmektedir. ${ }^{7}$ Aslında sosyal adalet kavramı ilk olarak İngiltere ve Fransa'da 1840'lı yılların endüstri uyanışı ya da devrimiyle birlikte ortaya çıkmış, 19. yüzyılın ekonomik ve sosyal eşitsizlikleri ile hız kazanmıştır. Bu bakımdan kavram işçi ve işveren arasındaki eşitsizliklerde, kapitalizmin ürettiği zenginlik ve gelirin paylaşımında bir araç olarak kullanılmıştır. ${ }^{8}$ Bununla birlikte sosyal adalete piyasa serbestisi açısından bakan liberal yaklaşım, müdahale ya da baskı kavramını oldukça dar yorumlamakta ve refahın paylaşımına destek vermemektedir. Diğer yandan ilerici yaklaşım ise baskı ya da müdahale kavramı bakımından daha geniş bir yoruma sahip olup refahın dağılımına destek vermekte ancak bunu "firsatların adil dă̆ılımı" seviyesine indirgemektedir.9 Bir başka yaklaşıma göre sosyal adalet komüniteryan özellikte yani kolektif problemlerin, kolektif olarak halledilmesi şeklinde öngörülmektedir. Buna göre insanın refahı için gerekli temel koşulların, ekonomik ve sosyal hakların adil dağılımının, bireylerin siyasi ve sosyal yaşamın eşit katılımcıları olduklarının güvence altına alınmasını gerektirmektedir. ${ }^{10}$

SOLAS John, What Kind of Social Justice Does Social Work Seek, International Social Work, C.51, Sa.6, s. 814.

6 SOLAS, s.818.

7 BARRY Brian, Why Social Justice Matters, 1. Bask1, Cambridge, Polity Press, 2005, s. 355.

8 BARRY, s.5.

9 YATES Al, BARTLEY Anne, Progressive Thinking: A Synthesis of American Progressive Values, Beliefs and Positions, American Values Project, Denver, 2012, www.tr.scribd.com/ document/131793272/Progressive-Thinking (erişim 16.01.2019)

10 WILEY, Lindsay F., Health Law as Social Justice, Cornell Journal of Law And Public 
Öte yandan sosyal adalet kavramı, toplum içerisinde adaletle ilgili tüm gelişmeleri yansıtan ve son zamanlarda ekonomi alanın bir uzantısı olarak görülmeye başlanan ve kavramı daha geniş bir alana taşıma isteği ile ilgili bir ideal olarak görülmektedir. ${ }^{11} \mathrm{Bu}$ noktada sosyal adalet kapsamında dağıtım ya da paylaşım kavramı ekonomik eşitsizliklere yönelirken, tanıma yaklaşımı ise kültürel ayrımcılığa yönelmektedir. Buna göre sosyal adalet hem ekonomik hem de sosyal değerler bakımından ortaya çıkan eşitsizliklerin dengelenmesini hedef edinmektedir. ${ }^{12} \mathrm{Bu}$ noktada sosyal adalet, mallarm eşit paylaşımını öngörmekle birlikte bu yaklaşım, bünyesinde bazı soruları barındırmaktadır. Eşit davranılmayı kimler hak edecektir? Ayrıca tarafsız ya da eşit olarak dağıtılacak mal/değer nelerdir? İlk soruda moral değerlere dayalı bir yaklaşım sergilenebileceği gibi daha somut bir belirleme yapılarak tüm insanların eşitliğinden de bahsedilebilir. Ancak bu sorunu çözmeyecektir. Zira toplumdaki herkesin eşit olduğu ya da eşit saygıyı hak ettiği düşüncesi tam olarak kabul görmüş bir yaklaşım değildir. Belirli özel durumlar haricinde genel olarak adaletin tesisi eşitliği ve tarafsızlığ 1 gerektirmemektedir. Burada karşılıklı saygının sağlanabileceği kurallar temelinde adaletin evrensel ilkelerine dönüş yapmak gerekecektir. ${ }^{13}$ İkinci sorunun cevabına dair pek çok felsefi cevap bulunmakta olup bunlardan bazıları ise oldukça soyut anlamlar içermektedir. Bununla birlikte eşit dağıtıma tabi tutulacak malın/değerin temel ya da birincil nitelikteki mallar ve değerler olduğu düşünülmektedir. Bu yaklaşım birincil mal ya da değerler "rasyonel, makul bir insanın öncelikle isteyeceği mal ya da değerlerdir" faraziyesine dayanmaktadır. Genel olarak bu değerleri, haklar, özgürlükler, fırsatlar, itibar, refah, gelir ve güç şeklinde ifade edebiliriz. Ancak bunun net ve somut bir sonuca ulaşması zor görünmektedir. Zira adalete ulaşmak için ampirik yollar bulmak mantıksız karşılanmaktadır. ${ }^{14}$

\subsection{Sosyal Adaletin Sağlanmasında Moral Değerler Etkili Midir?}

Sosyal adalet ile ilgili olarak başlıca moral değer, kişisel menfaat olarak ileri sürülebilir. Buna göre kişisel menfaat kavramı sosyal adaletin sağlanmasına yönelik siyasi adımların atılması bakımından tekrar tanımlanabilir. Yine empati

\footnotetext{
Policy, C.24, s.52.

11 WILEY, s.54.

12 FRASER, Nancy, From Redistribution to Recognition?: Dilemmas of Justice in a "Postsocialist" Age, New Left Review, C.212, Sa.1, July-August, s.68-69.

13 DIAS, Maria Clara, Affirmative Action and Social Justice, Connecticut Law Review, C.36, s. $871-872$.

14 DIAS, s. 873-874.
} 
duygusunun geliştirilmesi başkalarını düşünerek hareket etme motivasyonunu arttıracaktır. Bununla birlikte kişisel menfaat ve empatinin başlı başına sosyal adaletin tesisinde düşünülemeyeceği, bu iki unsurun siyasi dayanışma meydana getirerek, siyasi hareketlilik bakımından değerlendirilmek suretiyle amaca ulaşılabileceği dile getirilmektedir. ${ }^{15}$ Buna karşın kişisel menfaat kavramı üzerinde durmamı sosyal sorunları ve bunların farklı yollardan çözüm yollarını anlamamızı sağlamaktadır. Kişisel menfaat düşüncesinde her birey yalnızca kendi şahsi durumundan sorumludur. Bu nedenle, bu düşünce sosyal problemlerde kolektif sorumluluk yerine bireyin kendisine dayalı çözüm yollarını tercih eder. Bu noktada bir ayrıma gidilmektedir. Kamusal çözüm yolları sosyal problemlerin çözümüne ayrılmalıdır. Bireyler ise kendilerinden kaynaklanan sorunların çözümünde kendi başlarının çaresine bakmalıdırlar. Buna göre yoksullukla mücadelede çalışma programları ya da farklı sigorta modelleri gibi kişilere dayalı bireysel çözüm yolları üzerinde durulmalıdır. ${ }^{16} \mathrm{Bu}$ noktada sosyal adaletsizliklerin giderilmesi sosyal idealler ve sosyal gerçekliklerin bağdaştırılmasına çabalamaktadır. ${ }^{17}$

Yine bu noktada adalet düşüncesinin teleolojik yaklaşımların yanı sıra faydacılığa dayandırıldı̆̆ 1 ifade edilmektedir. Faydacı yaklaşım ise popüler, tarihi bir etik yaklaşım olmakla birlikte sosyal kararların alınmasında önemli bir fonksiyona sahip olduğu dile getirilmektedir. ${ }^{18}$ Faydac1lıkta toplumdaki tüm kurumlar, bireylerin yöneldikleri faydaya ulaşabilmeleri ve tatmin edilmeleri için kurgulanmaktadır. Faydacılık yaklaşımı haklar-ödevler, imtiyazlar-firsatlar gibi refah biçimlerinin tatminini sağlayıcı şekilde, en yüksek seviyede tahsis edilmelerine yönelir. Bununla birlikte bu yaklaşım tüm bireylerin tatminini garanti etmemektedir. Bu noktada faydacılığın sosyal adaletin sağlanmasında başlangıç noktası olduğu düşünülmektedir. ${ }^{19}$ Öte yandan sosyal adaletsizlikleri önlemek için moral değerler ile toplumda karşılık bulan materyal varlıkların bir potada eritilmesi gerektiği düşünülmektedir. ${ }^{20}$ "Olumlayıcı davranış"

15 ROBERTS, Dorothy E., Sources of Commitment to Social Justice, Roger Williams University Law Review, C.4, s.203.

16 ROBERTS, s.179.

17 PERLSTADT, Harry, Court Decisions, Social Problems and Social Justice, ALSA Forum, (American Legal Studies Assoc.), C.8, Sa.2, s.323.

18 SOLAS, s. 814.

19 SOLAS, s. 815-816.

20 SYTNiChENKO, Liudmyla, Otfried Hoffe's Theory of Social Justice, Polish Political Science Yearbook, C.44, s. 23. 
(affirmative action) olarak adlandırılan yaklaşım ise sosyal adaletin dayandırıldığı bir diğer moral değer olarak ifade edilmektedir. Bu yaklaşıma göre birey kendi yeteneklerini geliştirip geçmişin adaletsizliklerini giderebilir. Buna göre olumlayıcı davranışın toplumu dönüştürüp daha uyumlu ve toleranslı hale getirebileceği ileri sürülmektedir. ${ }^{21}$

Son olarak sosyal adalet kavramı tartışılırken konuya iki farklı açıdan bakıldığ 1 görülmektedir. Buna göre sosyal adalet, toplumun tümüne yönelik soyut bir ideal olarak ele alındığı gibi birey temelli ve toplumda pratiği olan bir değer olarak da ele alınmaktadır. ${ }^{22} \mathrm{Bu}$ bireyin yaşam alışkanlıklarını etkileyen ve değiştiren bir etkiye sahiptir. ${ }^{23}$ Buna göre değer, bir davranış bir beceri olarak görülebilir. Her zaman sergilenmeyen ancak kişide mevcut halde barınan değerler bireyin tutku ve duygularını yönlendirmesine yardımcı olur. Buna göre değerler bireyi diğerlerinden ayrı, fark edilebilir bir kişilik olarak ortaya çıkarır. ${ }^{24}$ Diğer yaklaşıma göre ise sosyal adalet, birey pratiğine dayalı değer taşıyan bir kavram olarak düşünülmez. Sosyal devlet topluma dair bir idealdir. Buna göre sosyal adalet bireyin aksine topluma ait bir karakter özelliği göstermekle birlikte devletin bir fonksiyonunu göstermektedir. Buna göre vatandaşlık kavramına dayalı bireysellikte, değerlere yer verilmemektedir. Devletyaptırım gücünü kullanacak ve değerler yerine bu fonksiyonunu işletmek suretiyle topluma müdahil olacaktır. Bu çerçevede sosyal adalet kavramı ile "devletin zorlayıcı gücünü kullanarak gelir dağılımını gerçekleştirmesi” ifade edilmek istenmektedir. ${ }^{25}$

Yukarıda yapılan açıklamalar doğrultusunda sosyal adalet kavramının moral değerlerin etkisinde kaldığ 1 sonucuna varmak mümkündür. Toplumun genelinde hâkim olan yaklaşım ya da moral değerin sosyal adaletin gerçekleşmesinde etkisi bulunmaktadır. Örneğin faydacı yaklaşım sosyal adaletin sağlanmasında olumlu bir etkiye sahip olmakla birlikte toplumun tümünü kapsayıcı bir etkisi bulunmamaktadır. Öte yandan birey menfaatinin mutlak üstünlügünün değil de kolektif mantalitenin bir değer olarak hâkim olduğu toplumlarda sosyal adaletin sağlanması daha mukadderdir.

\footnotetext{
21 DIAS, s.877.

22 NOVAK, s. 880.

23 NOVAK, s. 881.

24 NOVAK, s. 880.

25 NOVAK, s. 881.
} 


\subsection{Sosyal Adalet Hukuk, Toplum, Birey İlişkisini Nasıl Etkiler?}

Adalet bireylerin karşılıklı hoşgörüsüne dayalı olarak kurallara uyumundan ziyade toplumsal sınıfların hoşgörüsü ve uyumu olarak dile getirilmektedir. ${ }^{26}$ Günümüz açısından hukuk kurallarının özel olarak yoksulları kollayıcı nitelikte olmadığ 1 , bunun yerine toplumun genel refahı düşüncesinden hareket edildiği dile getirilmektedir. ${ }^{27}$ Buna göre kanunlar sadece yasama yoluyla oluşturulmaktan ibaret olmayıp yarg1 yoluyla da yorumlanmaya muhtaçtır ve bu noktada sosyal adalet kavramı devreye girmektedir. ${ }^{28} \mathrm{Bu}$ noktada hukuk ile ilgili pek çok teori olmasına karşın şu bir gerçektir ki hukuk daima kesimler arası ilişkiler, değerler ve teknolojik gelişmeler gibi toplumsal ya da sosyal değişimleri takip etme ve bunlara meşruluk kazandırma eğilimindedir. ${ }^{29}$ Bununla birlikte çoğu sosyal reform hareketleri toplumdaki belirli kesimlere dair sosyal problemlere yol açtıkları düşünülen kanunlar, kurallar ya da düzenlemelerin ortadan kaldırılmaları talep edilmektedir. ${ }^{30}$ Yine hukuk, sosyal problemlerin çözümünün, bireylerin dönüşümünün, toplumun organizasyonel yapısının değiştirilmesinin ve genel olarak değişimin teşvik edici gücü olarak dile getirilmektedir. ${ }^{31}$ Sosyal reformlar kişisel dönüşümlerden üstündürler ve öncelikle gerçekleşirler. $\mathrm{Bu}$ üstünlük belki de tek moral zorunluluk olarak kabul edilmektedir. Buna göre daha iyi sosyal kurumlar insan varlı̆̆ını yüceltmektedir, bunun aksi ise aynı sonucu doğurmamaktadır. ${ }^{32}$ Diğer yandan resmiyetin, kurumsallığın ya da hukuk usulünün gelişmediği sistemlerde dini inancın, bilimsel ya da ideolojik güçlerin yargı kararlarını etkilemesine kapı aralanmakta olduğu dile getirilmektedir. Bu durumda sistem pratiğe ve geleneksel yargılara dayanmaya meyil etmektedir. İşte bu noktada sistem, yargıya uyuşmazlıkları yargısal idealler ve sosyal gerçeklikler arasında çözümleme imkânı sunmaktadır. ${ }^{33} \mathrm{Bu}$

26 POUND, Roscoe, Social Justice and Legal Justice, Centeral Law. Journal, C.75, s. 455.

27 HAZARD, Geoffrey C.Jr., Social Justice through Civil Justice, University of Chicago Law Review,C.36, s.703.

28 PERLSTADT, s.314.

29 PERLSTADT, s.315.

30 PERLSTADT, s.316.

31 PERLSTADT, s.316.

32 FORTIN, Ernest L., Natural Law and Social Justice, American Journal Jurisprudence, C.30, s.15.

33 PERLSTADT, s.316-317. Aynı eser ve sayfalarda ABD Yüksek Mahkemesi’nin Wisconsin v. Yoder (1972) kararında devletin zorunlu eğitim talebiyle Amish toplumunun dini inanış ve yaşam tarzı arasında bir denge kurduğuna değinilmektedir. 
bakımdan sosyal adaleti sağlamak mümkün k1lınabilir. Ancak bu durumda da yarg1 sistemi daha informal hale gelecek ve istikrarını kaybedecektir. ${ }^{34}$ Modern hayat ise hukuku sosyalleştirmektedir. Geçmişte hukuk konseptinin doğal haklar arasında bir köprü olarak kurgulandığg ve toplumun bu bağlamda bir değer olarak ele alınmadığı düşünülmektedir. ${ }^{35} \mathrm{Bu}$ noktada sosyal adalet topumun haklarını ve toplumsal sinif davası yoluyla toplumun kendini koruyabilmesini kapsamaktadır. ${ }^{36}$ Bununla birlikte sosyal adalet anlayışı, dönüşümüne ve gelişimine devam ederken adalet temeli üzerine inşa edilmekte, hakların ve kaynakların kullanımı, kullanım kapasitelerinin paylaşımı ve toplumun dönüşümü ile sağlam bir toplumsal yapıya ulaşmak hedeflenmektedir. ${ }^{37}$ Buna göre sosyal içerikli düzenlemeler yüzyılımızın önemli adımlarından birisi olarak görülmektedir. İnsan gücünün yerini makine gücünün alması insanların yaşamak için eskiye nazaran daha az didinmelerini sağlamakla birlikte sanayileşme özellikle sağlık ve özgürlük bakımından önemli tehlikeleri barındırmaktadır. ${ }^{38}$ Zira sosyal adaletin sağlanmasında aktif devletin kullanacağı önemli yöntemler bulunmaktadır. Bu yöntemlerden birisi özel mülkiyetin ve ekonomik gücün asosyal kullanımının düzenlenmesidir. Buna göre hukuk sosyal ilişkileri dönüştürme ve hali hazırdaki dönüşümleri dikkate alma potansiyeline sahiptir. ${ }^{39}$ Özellikle "common wealth" yarg1 sisteminde sosyal haklar yoluyla sosyal adaletin temininde, yargıçların somut pratikler üzerinden içtihatlar geliştirebildikleri ve bu yolun anayasal açıdan daha çok verimlilik taşıdığı düşünülmektedir. ${ }^{40}$

Bireyler arası ilişkilerde sosyal adalet bakımından bazı değerlendirmeler yapıldığ 1 görülmektedir. Buna göre günümüzde var olan sosyal çekişmelerde sosyal adalet konusu nazara alınmamaktadır. Özel hukukun büyük bölümü, ekonomik iddialar temelinde, sosyal karışıklık ya da anlaşmazlıklardan kaynaklanmaktadır. Bu noktada veraset vergisinden, mülkiyete, kefaletten bankacıllğa, ortaklık hukukundan gerçek kişi girişimlerine kadar sözleşme

\footnotetext{
34 PERLSTADT, s.317.

35 GOTTLIEB, s.33.

36 PERLSTADT, s.318.

37 KALSEM, Kristin, WILLIAMS, Verna L., Social Justice Feminism, UCLA Women's Law Joirnal, C.18, s.150-151.

38 GOTTLIEB, s.34.

39 EWING Keith, Just Words and Social Justice, Review of Constitutional Studies, C.5, Sa.1, s.74.

40 EWING, s.71.
} 
ve tazminata dayalı uyuşmazlıkların çoğunun sosyal dinamikleri üzerinde durulmamaktadır. Bubakımdan ortaya çıkan sorunların temelinde özel hukukun özelliklede ticaret ve sözleşmeler hukukuna hâkim olan ilkelerin var olan sorunları arttırdığına değinilmektedir. Bu nedenle sadece teknik bir anlayışla sosyal dinamikleri göz ardı etmek suretiyle uyuşmazlıkları ele almak, taraflar açısından vakit kaybına, ayrıntılarda boğulmaya ve davaların maliyetinin artmasına sebep olacaktır. Bu durumda da yoksulların mahkemelerde adalete ulaşma şanslarının düşük olacağı inancının yaygınlaştığı düşünülmektedir. ${ }^{41}$ $\mathrm{Bu}$ bağlamda yoksulların yargı süreçlerinde dezavantajlı ve haklarından mahrum konumda oldukları değerlendirmesi yapılmaktadır. ${ }^{42}$

Diğer yandan bazı durumlarda hukukta yaşanan değişimin, kuralları değiştirmenin ötesinde toplumdaki kültürel-sosyal yapıyı değiştirip dönüştürmek üzere gerçekleştirildiği düşünülmektedir. ${ }^{43}$ Sosyal adalet tesis edilsin ya da edilmesin şurası bir hakikattir ki sosyal adalet kavramı görmezden gelinemeyecek ya da gözden kaçırılacak bir kavram değildir. Hukukun sosyal adaletin tesisindeki rolü oldukça karmaşıktır. Zira hukuk, toplumun tüm kurumlarını kontrol etmekle birlikte kendisi de başlı başına toplumun bir kurumudur. Yönetici kesimin toplumun geniş kesimlerine hesap vermesinin aracıdır. Hukuk, toplumun bir parçası olarak bünyesinde doğal hukukun gereklerini barındırmalıdır. Buna göre hukuk, toplumdaki değerlerle bunların icrası arasında bir köprü görevi görmektedir. ${ }^{44} \mathrm{Bu}$ bakımdan hukuk sosyal dinamiklerle beslenmekte ve meşruiyetini sosyolojik kabullerde bulmaktadır. $\mathrm{Bu}$ nedenle hukuk özellikle de anaysa yargısı, refahın ve demokrasinin toplumsal tabana yayılmasında önemli bir rol üstlenmektedir. Aksi takdirde, toplumlar belirli bir zümreye hasredilmek suretiyle refaha ya da demokrasiye sahip olabilirler ancak hiçbir zaman her ikisini birden aynı zümrenin eline veremezler. ${ }^{45}$ Yani hem demokrasi hem refah toplumun belirli bir kesiminin elinde birleşebilecek bir konumda değildir. Bu noktada sosyal adalet zenginliğin yani refahın toplumun tüm kesimleriyle paylaşımı ile birlikte demokrasinin

${ }^{41}$ WEHLE, Louis B., Social Justice and Legal Education, American Law Review, C.51, s.6.

42 O'SHANE, Pat, Social Justice for Aborigines, Alternative Law Journal, C.19, Sa.1, February, s. 19.

43 HUNTER, Nan D., Lawyering for Social Justice, New York University Law Review, C.72, November, s. 1009.

${ }^{44}$ RODES Robert E. Jr., Social Justice and Liberation, Notre Dame Law Review, C.71, s. 619.

45 COLLINS Chuck, YESKEL Felice, Economic Apartheid in America: A Primer on Economic Inequality and Insecurity, 1. Bask1, The New Press, New York, 2000, s. 69. 
de toplumun tamamına yayılmasına hizmet etmektedir. Bu bakımdan sosyal adaletin tesisinde politika ve hukuku ayrı kulvarlarda değerlendirmek gerekmektedir. Buna göre bir iftiraya uğradığınızda ya da dolandırıldığınızda, kendinize bir avukat arayabilirsiniz, ancak işsizlik, sağlık hizmetlerinden eşit yararlanamama ya da yoksullukla karşılaştığınızda, gözünüz seçim sandığına ya da medyaya yönelmektedir. Fakat bu farklılığa rağmen değişime uğramış ve gelişmiş ülkelerde böylesi sosyal konularda dahi siyaset yerine hukuki mekanizmalara yönelme eğilimini ortaya çıkartmaktadır. Buna göre politika ve politikacılara yönelik ümitlerin azalmasına karşın hukuk ve yargıya daha fazla ümit bağlanmaya başlanmıştır. ${ }^{46} \mathrm{Bu}$ noktada "hukukun sosyal adalet dağıtıp dağıtamayacağı" sorusu gündeme gelmekte ve bu soru günümüzün en önemli anayasal sorunlarından birisi olarak düşünülmektedir. Bu durumda, en azından "insan hakları ile ilgili olan kısımlar bakımından sosyal adaletin tesisinde hükümetler yerine yargıya bir yetki ya da güç aktarımı yapabilir miyiz?" sorusu dile getirilmekte ve böyle bir güç aktarımının yapılamayacağ 1 bazı gerekçelere dayandırılmaktadır. Her şeyden önce, insan haklarının içerik ve detaylarını tayin hakkı konusunda parlamentolar esas alınmalıdır. Yarg1 ise içeriksel bir belirleme yapmadan insan haklarının icrası ile ilgilenmeli ve insan haklarına uygun düşmeyecek hükümlerin iptaline yönelmelidir. Buna göre bir temel haklar bildirgesinin amacı sosyal adaleti tesis etmek olamaz. $\mathrm{Bu}$ konuda demokratik olarak yönetime gelmiş hükümetlerin yetkinliklerine sayg1 duyulması gerekmektedir. Zira kanunları düzenlemekle sosyal adalete ulaşılamayacağına dair bir yargıya varmak temel bir hata olarak değerlendirilmektedir. ${ }^{47}$ Bununla birlikte politikanın sosyal adaleti sağlama da başarılı olamaması halinde yukarıda bahsi geçtiği üzere sorun insan hakları temeline anayasal bir sorun haline gelip anayasa yargısına taşınabilecektir. $\mathrm{Bu}$ kapsamda sosyal yardımların pozitif etkisi, toplumu kolektif iyiye doğru teşvik ederken maliyetlerin negatif etkisi, tepkiye ve karşı çıkışa yol açabilmektedir. ${ }^{48}$ Buna göre sosyal refah programlarının maliyeti arttıkça vergi veren kesimler üzerindeki mali yük artacak ve vergi veren kesim sosyal yardımların daha varlıklı kesimlere yüklenmesini ya da bu yardımların azaltılmasını talep edilebilecektir. Buna karşın, özellikle de tıbbi içerikli sosyal yardımlar yargı

\footnotetext{
46 CAMPBELL, Tom, Can the Law Deliver Social Justice, University of Western Sydney Law Review, C.5, s.51.

47 CAMPBELL, s.51-52.

48 PERLSTADT, s.321.
} 
kararları aracılığıyla garanti edilmelidir. ${ }^{49}$ Sosyal yardımlar sağlanırken vergi yükü artan mükelleflerin talepleri de dikkate alınmalı ve kesimler arasında bir denge oluşturulmalıdır. Zira anayasal zeminde konu ele alınacak olursa toplumun bir kesiminin, yoksulların, sağlık hakkı ile diğer kesiminin, vergi mükelleflerinin, mülkiyet hakları arasında bir dengenin tesisi gerekmektedir. Sosyalist öğretide ise toplumun tüm alanlarında olduğu gibi sosyal adaletin sağlanmasında da Partinin rolü öne çıkmaktadır. Bu kapsamda sosyal adalet farklı sosyal grupların yaşam şartları arasında eşitliğin sağlanmasında bir ölçü ya da "ayar" olarak ele alınmaktadır. Bu "ayar" toplumun materyal ve entelektüel olgunluğuna bağlı olup tüm çalışan ya da emekçilerin temel menfaatlerini içermektedir. ${ }^{50}$ Bununla birlikte gelir elde etme bakımından hangi düzeyin asgari yaşam şartı olacağı toplumdan topluma değişkenlik göstermektedir. Buna göre kaynakların oldukça sınırlı olduğu fakir bir toplumda yaşam standardı gerekliliği bir insan hakları sorunu olabilir. ${ }^{51} \mathrm{Bu}$ noktada ekonomik olarak yaşanacak her adaletsizlik sosyal devlete karş1 işlenmiş bir günah olarak görülmektedir. ${ }^{52}$ Toprak soyluluğun yani toprak sahibi aristokrasinin bulunduğu ülkelerde mülkiyet hakkının daha kutsal bir görünümde olduğu, buna karşın bu anlayışın sanayileşen, kalabalık nüfuslu toplumlarda yer bulamayacağı dile getirilmektedir. ${ }^{53}$ Ancak sanayileşen toplumlarda sosyal adaletin tesisinde mülkiyet hakkını farklı boyutlarıyla tartışmaya açabilecektir. Örneğin şehirleşmenin yoğun olarak yaşandığı bölgelerde göç ve buna dayalı olarak şehrin farklı yerleşim alanları arasındaki sosyal dengesizlikler yaşam kaliteleri bakımından yeni sorunları ortaya çıkartabilecektir. Bunun çözümü ise yeni sosyal politikalar geliştirebilmektir. Buna göre sosyal politikaları sadece nakdi ya da gıda yardımı gibi ayni yardım şeklinde anlamak elbette ki sorunlara çözüm üretmeyecektir. Hatta böyle bir yaklaşım sosyal yardımlara bağımlı bir şekilde yaşamlarını sürdüren kesimler bakımından sorunların kronikleştirilmesi anlamına gelecektir. Bu noktada bireyleri yardımlara bağımlı hale getirmek yerine kapitalizmin olumsuz yönlerini törpüleyecek nitelikte sosyal politikaların benimsenmesi daha yararlı olacaktır. Bu bakımdan sosyal yardımların en azından çalışma imkânı bulunan

\footnotetext{
49 PERLSTADT, s.322.

50 ROGOVIN, V., Social Justice and Improving Distribution Relations, Soviet Law and Government, C.25, Summer, s. 3.

51 Wellman, Carl, Social Justice and Human Rights, Persona \& Derecho, C.17, s.211.

52 NOVAK, s. 879-880.

53 GOTTLIEB, s.38.
} 
bireyler bakımından sosyal çalışma programları kapsamında yapılması, yardımları bağımlılık haline gelmekten çıkartıp alın terinin karşılığı haline getirecektir. Bu durum sosyal yardımlardan faydalananlar içinde olumlu bir etki oluşturacaktır.

\section{SOSYAL ADALETİN BAZI TEMEL HAKLARA ETKİLERİ}

Sosyal adalet kavramı bir adalet ve eşitlik tasavvuru olarak küresel seviyede genişlemesini sürdürmektedir. $\mathrm{Bu}$ bakımdan sosyal adaletin ilkeleri, insan hakları ve insan onuru için küresel bir mücadelenin parçası olarak anlaşılmaktadır. ${ }^{54}$ Sosyal adalet ile insan hakları arasında yakın bir ilişki bulunmaktadır. Örneğin cinsiyete dayalı sosyal adaletsizlikler, hukuk önünde eşit korunma ve firsat eşitliğini sağlayan temel hakların ihlali sayılarak, eleştirilmiştir. Zengin olanın lüks içinde olduğu, yoksulun ise temel gereksinimlerini bile karşılayamadığ 1 adaletsiz bir toplumda hayatta kalmayı sağlayacak temel standartlar, insan hakları sorunu olarak karşımıza çıkacaktır. Buna göre "sosyal adalet kavramı" siyasi ya da yargısal adalete indirgenemeyecek olup toplumdaki siyasi, yargisal ve ekonomik adalet ya da adaletsizlikleri kapsayan bir kavramdir. ${ }^{55}$ Yani sosyal adalet ve temel hakların örtüştükleri durumlarda söz konusu olabilmektedir. Buna göre toplumdaki tüm bireylerin eşit olarak temel haklara sahip oldukları düşüncesi ya da temel haklara saygının sosyal adaletin esaslı bir buyruğu olduğu inancı bu iki kavramın birbirine yakınlaştığ durumları ifade etmektedir. ${ }^{56}$ Aslında sosyal adaletin temelinde eşitlik kavramı yatmaktadır. Zira sosyal adalet üzerinde verilen büyük tarihi mücadelelerin hepsi eşit haklar temeline dayanmıştır. ${ }^{57}$ Buna göre en azından toplumdaki tüm bireyler insan onuruna sahip olma bakımından eşittirler. Hatta suç işlemek suretiyle toplumun geneline zarar vermiş olan bireyler dahi insan onuruna uygun cezalarla cezalandırılmalıdırlar. Buna karşın sosyal adalet ve temel haklar arasında doğrudan ve mantıksal bir bağlantı kurulmasının doğru olmadığı da ileri sürülmektedir. Buna göre temel hak ihlali niteliğinde olmasına rağmen adaletsizlik olarak değerlendirilmeyen pek çok durum söz konusu olmaktadır. Örneğin savaş sırasında askerin bir düşman askerini öldürmesi yaşam hakkına yönelmesine rağmen adaletsizlik ya

54 KALSEM, WILLIAMS, s. 150.

55 WELLMAN, s.199.

56 WELLMAN, s.213.

57 WELLMAN, s.205. Yine eserin aynı yerinde, tarihte verilen büyük mücadelelerin siyasi mutlakiyetçiliğe, ekonomik sömürüye, köleliğe, düşük sınıfların haklarından mahrum edilmelerine karş1 yürütüldüğü belirtilmektedir. 
da moral değerlere bir aykırılık olarak algılanmamaktadır. ${ }^{58}$ Görüldüğü üzere eşitlik her zaman adaleti doğurmamaktadır. Buna göre masum bir insana ceza verilmesi bireysel olarak bir adaletsizlik olsa da bu kişiye diğer bireyler gibi eşit bir yargılama yapıldı ğından bahisle adaletli davranıldığı iddia edilemez. Diğer yandan toplumdaki tüm bireyler için eşit mesafede durulmak suretiyle suçluların tespitinde zar atılması ya da günlük olarak açılan ilk on beş dosyada mahkûmiyet diğerleri ile ilgili beraat kararı vermek gibi uygulama getirilse tüm bireylerin eşit olduklarından bahisle herhangi bir adaletsizliğin olmadığını ileri sürmek imkansızdır. ${ }^{59}$

Diğer yandan insan haklarının korunması bakımından dönüşümsel adalet bazı ülke ya da toplumlar bakımından önemli etkilere sahiptir. Özellikle Güney Afrika'da 1996 y1lındaki yeni anayasa ile birlikte eski yönetimin ideolojisinin kırıldığı en azından yumuşadığ dile getirilmektedir. ${ }^{60}$ Böylece Güney Afrika'da olduğu gibi yeni anayasalar sosyal değişimin yeni dili olarak uygulanmak üzere hazırlanmışlardır. ${ }^{61}$ Dönüşümsel adalet süreçleri, baskıcı yönetimin mağdurlarının güçlendirilmesiyle birlikte rejimin ideolojisinin dönüşümünü sağlamaktadır. Böyle bir süreçten makul olarak beklenen netice, kötü sonuçlar doğuran baskıcı ideolojinin dönüşümünü temin suretiyle adaletin güçlenmesi ve güvenin sağlanmasına katk1 sağlamaktır. ${ }^{62}$ Buna göre dava hakkının temel bir hak olarak tanınmasının ve bu yolla hak aramanın, yoksulların durumlarını önemli oranda iyileştirebileceğine vurgu yapılmaktadır. Buna karşın bu durumun uygulamada aynı sonucu vermediği ve gerekli koruma ve imkanların sağlanmadan, dava yoluyla yoksulların lehine adımlar atılamayacağı ileri sürülmektedir. ${ }^{63}$ Sosyal adaletin sağlanmas1 konusunda ortaya çıkan uygulamalardan birisi de kota uygulamalarıdır. Buna göre siyasi alanda, özellikle kadın ve engelli adayların temsiline yönelik kota uygulamaları, yine eğitimde belirli okullar açısından belirli kesimler için getirilen kota uygulamaları, bunlardan bazılarına örnek olarak gösterilmektedir. Bununla birlikte zengin ve yoksul arasındaki fark ya da ayrım bakımından bu kotaların uygulanma imkânı bulunmamaktadır. Buna

58 WELLMAN, s.201-205.

59 WELLMAN, s.207.

60 SANDOVAL Clara, Transitional Justice and Social Change, SUR - International Journal on Human Rights, C.20, s. 183.

${ }^{61}$ SANDOVAL, s.181.

62 SANDOVAL, s.187.

63 HAZARD, s. 699. 
karşın Brezilya gibi ülkelerde ortaya çıkan sıfır açlık (zero hunger) ${ }^{64}$ ya da aile yardım $1^{65}$ (the family grant) gibi bazı sosyal projelerin, mevcut farkın azalmasında etkili olduğu dile getirilmektedir. ${ }^{66}$

Sosyal adalet kavramı elbette ki pek çok temel hak ile ilişkilendirilebilir. Bununla birlikte çalışmamızı sınırlandırabilmek adına sosyal adalet kavramı çocuk hakları, çevre hakkı ve sağlık hakkı ve cinsiyet ayrımcılığı bakımından ele alınmaktadır. Bu başlıkların belirlenmesinde çocuk ve kadınları ilgilendiren uzun soluklu tartışmaların yanı sıra günden güne artan çevre kirliliği ve gelişen sağlık teknolojileri karşısında sosyal adaletin durumu ve etkilerini sergileyebilme düşüncesi etkili olmuştur.

\subsection{Sosyal Adalet ve Çocuk Hakları}

Sosyal destek programlarında özellikle yoksul çocuklara karşı bir ilgi ve desteğin olmasına karşın yetişkin yoksullara karşı böyle bir ilginin olmadığı düşünülmektedir. Buna karşın öncelikle ebeveynlere yönelik programların geliştirilmesi ve bunların refah seviyelerinin arttırılması zaten çocukların yoksullarını ortadan kaldıracaktır. Buna göre ebeveynlere yönelik gerekli düzenlemelerinyapılıp çocuklarına bakabilecek yeterligelirielde edebilecekleri gerekli iş imkânı ve çalışma koşullarının sağlanması gerekmektedir. Yine bir anayasal demokraside, yönetim, çocuklara, vatandaş olarak haklarını ve sorumluluklarını bilebilecek düzeyde bir eğitimin verilmesinde önemli bir rol oynamalıdır. ${ }^{67}$ Öte yandan çocuk sahibi olma hakkının anayasa ile sağlanan ve korunan temel bir hak olduğu ancak bu hakkın kullanımı nedeniyle ortaya çıkacak ekonomik sıkıntıların yükünün sosyal yardımlar üzerinden diğer

${ }^{64}$ Sıfır Aç (Zero Hunger) programı 2003 yılında Brezilya hükümeti tarafından açlık ve yoksulluğa son vermek için başlatılmış bir programdır. Program çocukların beslenme bozukluğunun ve güvensiz gıdaların tüketiminin azalmasını sağlamış ve bazı Afrika ülkelerine örnek olmuştur. Program, küçük çiftçilere eğitim ve teçhizat desteğinin sağlanarak okul gıdaları, kamu restoranları ve gıda bankalarına doğrudan bu çiftçilerin mamullerinin alınması esasına dayanmaktadır. www.globaljustice.org.uk/blog/2013/sep/12/brazils-zerohunger-programme-working (erişim 02.10.2019)

${ }_{65}$ Aile yardımı (the family grant) programı 2004 yılında Brezilya hükümetince uygulamaya konulmuş bir programdır. Program kapsamında ailenin geliri dikkate alınmak suretiyle fert başına 60 Avroya kadar destek verilmektedir. Yine çocukların sayısı ve yaşına göre 14 ile 105 Avro aralığında yardımda bulunulmaktadır. www.journals.openedition.org/ factsreports/1314 (erişim 02.10.2019)

66 DIAS, s. 877.

${ }^{67}$ FOLEY, Edward B., Social Justice and Child Poverty, Ohio State Law Journal, C.57, s. 485. 
vatandaşların sırtına yüklenmesinin doğru olmayacağı dile getirilmektedir. ${ }^{68}$ Buna göre devletlerin yaptıkları yemek fişi, bakımevleri ve diğer sosyal yardımların maliyetinin büyük miktarlarda olduğu dile getirilmektedir. Bu durum göz önüne alındığında gelişmiş ülkelerde, her bireye asgari yaşamlarını sürdürebilecekleri belirli bir miktar tahsisatın yapılmasının daha verimli ve gerçekçi olacağı düşünülmektedir. ${ }^{69}$

\subsection{Sosyal Adalet ve Çevre Hakkı}

Sosyal adalet konusunda yaşanan bir diğer sorun da iklim değişikliğine bağlı ekonomik gelişmeler karşısında ortaya çıkmaktadır. Buna göre emisyon oranlarının yükselmesi yani karbon gazı salınımının arttırılması neticesinde verimli topraklara sahip olan ancak fakirlik çeken toplumların, toprak verimliliğini önemli bir gelire çevirebilecekleri düşünülmektedir. ${ }^{70}$ Buna karşın, karbon gazı salınımı bakımından belirli toplumların ise onarıcı adalet gereğince zararlı etkilerden sorumlu tutulması düşüncesi de gerçekçi bulunmamaktadır. Örneğin ABD'de karbon gazı salınımından sorumluluğu gündeme gelen kimselerin artık hayatta olmadıkları, bu nedenle de yarg1 bakımından dahi sorumlu tutulamayacakları ifade edilmektedir. ${ }^{71}$ Bununla birlikte ABD'nin karbon gazı salınımı diğer savunmasız ülkelere karşı önemli bir haksızlık olarak görülmektedir. Ancak ABD’nin iklim değişikliğinden zarar gören ülkelere yardım etme yükümlülüğünün öngörülmesinin de mevcut durum karşısında uygun bir yol olmayacağı dile getirilmektedir. Zira karbon gazı salınımının azaltılması ABD açısından diğer maliyetleri arttırıyorsa, zaten diğer ülkelere mali bir aktarımın yapılamayacağı ifade edilmektedir. ${ }^{72}$ Çevrenin korunması konusunda artan bilinç, sosyal adalet algısında da bir dönüşüme neden olmuştur. Buna göre sosyal adalet kavramı toplumun ya da kamunun yararı kapsamında tekrar tanımlanmalıdır. Buna göre iş imkânı, yeterli ve erişilebilir gıda ve yeterli sağlık hizmetine erişimin yanı sıra çevre hassasiyeti de sosyal adalet kavramının tanımlanmasında önemli bir dinamik olarak karşımıza çıkmaktadır. Toplumlar ekolojik, sürdürülebilir ekonomik aktiviteleri ve çevre istismarını göz önüne almak durumundadır. Devletler bu

\footnotetext{
68 FOLEY, s.510.

69 FOLEY, s.508-509.

70 POSNER, Eric A., SUNSTEIN Cass R., Global Warming and Social Justice, Regulation, C.31, Spring, s.17.

71 POSNER, s.18.

72 POSNER, s.20.
}

312 Ankara Hacı Bayram Veli Üniversitesi Hukuk Fakültesi Dergisi C. XXIII, Y. 2019, Sa. 4 
alanı düzenlemekle yükümlü olup ticari getiri kaygısıyla bu sorumluluktan kaçınma yoluna gidemeyeceklerdir. ${ }^{73}$ Sağlıklı çevre, çevrenin korunmasını esas alan, temel bir hak düşüncesi esasına dayanmaktadır. ${ }^{74} \mathrm{Bu}$ konuda yasama kadar yargıya da önemli bir görev düşmektedir. Yargı en azından yorum gerektiren konularda tavrını çevre hakkı lehine göstermelidir. Ancak bu durum yargı bakımından bir yükümlülük olmayıp bir tercih meselesi vaziyetindedir. Örneğin, İngiliz hukuk sistemi bakımından kirliliğin tanımının net olarak ortaya konulamadığı, dolayısıyla bu konuda özellikle de yargının hüküm kurması bakımından belirsizliklerin olduğu dile getirilmekte ve bunun sebebi olarak çevrenin korunmasına yönelik mevzuatın esnekliği öne sürülmektedir. ${ }^{75}$

\subsection{Sosyal Adalet ve Sağlık Hakkı}

Sağlık hukuku, sağlığın korunmasına dair bir hukuk alanı olmanın yanı sıra, sağlık hizmetinin sunulması ve finanse edilmesini de içeren bir kavramdır. Buna göre kamu otoritesi ve buyrukları, sağlıklı yaşam koşullarını garanti etmelidir. ${ }^{76}$ Sağlik alanındaki sosyal hareketlilik temelde üç noktada sıralanmaktadır. Bunlar, sağlık alanında yaşanan eşitsizlikler, sağlık ve sosyal adalet konusunda sosyal bilincin uyanması ve "sağlık adaleti" şeklinde suralanabilir. Sağlık adaletinin temel etkisi, hukukun bu alanda ortaya çıkan dengesizlikleri, eşitsizlikleri giderici ya da azaltıcı bir araç olarak kullanılmasıyla gerçekleşecektir. Buna göre sağlik adaleti yasal düzenlemeler ve reformlar için temel bir yapı ya da çerçeve işlevi görecektir. ${ }^{77}$ Öte yandan sağlık hakkına dayalı sosyal hareketlilik, çevre, üreme ve gıda ekseninde tasnif edilebilir. Tüm bu hareketliliklerin temelinde ise gelir dağılımında adaletsizlik, imtiyazlı toplum kesimleri, ableizm, ${ }^{78}$ cinsiyet ayrımcılığı ve nativizm ${ }^{79}$ gibi kavramlar yer almaktadır. ${ }^{80} \mathrm{Bu}$ bakımdan

\footnotetext{
73 O'SHANE, s.20.

74 WILEY, s.53.

75 MACRORY, R., Environmental Standards, Legitimacy and Social Justice, Acta Juridica, 1999, s.257.

76 WILEY, s.52.

77 WILEY, s.52-53.

78 Ableism, engelli bireylere karşı yapılan ayrımcılı̆̆ı ifade etmektedir. www.seslisozluk.net/ ableism-nedir-ne-demek/ (erişim 16.01.2019)

79 Nativizm, yerlilerin çıkarlarını koruma siyaseti olarak dile getirilmektedir. www.seslisozluk. net/nativism-nedir-ne-demek/ (erişim 16.01.2019)

80 WILEY, s.53.
} 
bahsi geçen kavramların doğru algılanıp gerekli yasal düzenlemelerin bu doğrultuda şekillendirilmesi daha uygun bir adım olacaktır. Sağlık hukuku bakımından bir diğer temel nokta, yoksulların sağlık hizmetine ulaşımında finansal erişilebilirliğin sağlanmasıdır. ${ }^{81} \mathrm{Bu}$ durumda karşımıza çıkan önemli bir uygulama zorunlu aşılama programlarıdır. Buna göre hukuk, uzun dönem sağlık planlamalarında bir araç olarak kullanılmaktadır. Bununla birlikte ABD'de çocukların aşılanma oranı düşük gelir seviyesine sahip ailelerde daha yüksek olmakla birlikte yüksek gelirli aileler aşı yaptırmaktan kaçınma eğiliminde olabilmektedirler. Bu durum aslında aşılama konusunda topluca hareket eden düşük gelir kesimine karşı, zenginlerin bir risk algısına kapılmalarına dayandırılmaktadır. Buna göre yüksek gelirliler, zorunlu ve ücretsiz olan ve düşük gelirliler tarafindan desteklenen, sürüyü koruma mantığından, sıyrılmak arzusu içerisinde olabilmektedirler. Bu noktada sağlık adaletinin hedeflerinden bir tanesi de toplum kesimlerinin sağlık uygulamaları karşısındaki algılarını ve davranış modellerini etkileyebilmektedir. ${ }^{82}$

\subsection{Sosyal Adalet, Feminizm ve Cinsiyet Ayrımı}

Yasal girişimlere zemin hazırlayan durum ve koşulların, siyasi taraflarının olmaması hukuk kurallarının da etkisiz ve tarafsız olmaları sonucunu doğurmaz. Sosyal yönetim siyasi eleştiriler tarafindan tamamen biçimsiz bir hale gelemez ve belirli bir grubun belirlemelerine indirgenemez. Örneğin feminist temelli siyasi düşüncelerin, hukuku şekillendirmesi oldukça yüksek düzeyde arzulanabilir. Bununla birlikte, cinsel taciz konusunda yasal önlemleri desteklemek için feminist olmak gerekmemektedir. ${ }^{83}$ Özellikle feminizme dayalı sosyal adalet anlayışı, bu konuda atılan adımları ve ortaya çıkan fikirleri genel bir çerçevede bizlere sunmaktadır. Buna göre feminizm bakımından kavramın doğuşu, yine kadınların iş hayatında yaşadıkları sıkıntılara çözüm önerisi olarak geliştirilmiş ve ileri sürülmüştür. Buna göre ilk olarak çalışma saatlerinin düşürülmesi, daha iyi bir asgari ücret ve daha iyi çalışma şartları şeklinde bir reform hareketi olarak yola çıkılmıştır. Bu reform hareketlerine, kadın hakları savunucusu kurumların müdahalesiyle birlikte feminist anlayış sosyal adalet zemininde ortaya çıkmıştır. Feminizme dayalı sosyal adalet anlayışında verilen mücadele, genel olarak alanı genişleyen iş hayatında,

81 WILEY, s.71.

82 WILEY, s.74-75.

${ }^{83}$ MINSON Jeffrey, Second Principles of Social Justice, Law Context: A Socio-Legal Journal, C.10, s.32. 
kadın çalışanların korunması esasına yöneliktir. Yine asgari ücretin altında yapılacak ödemeler kadın çalışanlar için de zararlı olup bu konuda alınan tedbirler yasal önlemlerle desteklenmelidir. ${ }^{84}$ Günümüzde yerleşik politika ve yapıların, kadın hakları iddiasına karşı halen direnmeye devam ettiği dile getirilmektedir. Bu noktada kadınlar için tam bir sosyal eşitlik düşüncesine karş1 getirilen engellerin açıkça cinsiyet temeline dayandırılmadığı, bunun yerine büyük oranda cinsiyetçi klişelerin ya da faraziyelerin içerisinde örtülü olarak devam ettirildiği belirtilmektedir. ${ }^{85}$ Örneğin vergilendirme konusunda ayrımcılığa dayalı bir sosyal eşitsizlik, aile içerisinde çalışan kadının, aile gelirine olan katkısının farklı yöntemlerle vergilendirilmesi bakımından ortaya çıkmaktadır. Buna göre evli kadının geliri ikincil gelir olarak değerlendirilip daha yüksek oranda bir vergilendirmeye tabi kılınabilmektedir. ${ }^{86}$ Görüldüğü üzere sosyal adaletin tesisinde kadın-erkek eşitliği önemli bir ağırlığa sahiptir. $\mathrm{Bu}$ konuda toplumdaki yerleşik ve olumsuz algıların değiştirilmesi her ne kadar bir süreç gerektirse de yasal düzenlemelerle bu konuda önemli mesafeler alınabilir. Bu konuda eşitliğin toplum her alanına yayılması için kota ya da teşvik gibi uygulamalar söz konusu olabilmektedir. Fakat bu konuda öncelikli görev yasamaya aittir. Yargı da önüne gelen uyuşmazlıklarda doğrudan anayasa hükümlerine ya da devletin taraf olduğu ve iç hukukun bir parçası haline gelen uluslararası sözleşmelere dayanarak ayrımcılı̆̆ 1 giderici adımlar atabilir. Ülkemiz yarg1 pratiği bakımından, bağlayıcılı̆̆ 1 olmasına rağmen, doğrudan Anayasa hükümlerine ${ }^{87}$ ya da uluslararası sözleşme hükümlerine ${ }^{88}$ dayanılmas1, maalesef, pek görülmedik durumdur.

\section{SOSYAL ADALET VE CEZA ADALETI}

\subsection{Genel Olarak}

Ceza adaletinin sağlanması bakımından sosyal adalet düşüncesine yönelik farklı yaklaşımlar bulunmaktadır. Bu noktada onarıcı adalet fikri ceza adaleti sisteminin dönüşümünü savunan bir sosyal hareket olarak karşımıza

${ }^{84}$ KALSEM, WILLIAMS, s.151-153.

${ }^{85}$ HUNTER, s. 1016.

86 STEWART, Miranda, Reforming Tax for Social Justice, Alternative Law Journal, C.23, Sa.4, August, s.161.

871982 Anayasası madde 11: "Anayasa hükümleri, yasama, yürütme ve yarg1 organlarını, idare makamlarını ve diğer kuruluş ve kişileri bağlayan temel hukuk kurallarıdır."

881982 Anayasası madde 90/son/1. cümle: “Usulüne göre yürürlüğe konulmuş Milletlerarası antlaşmalar kanun hükmündedir." 
çıkmaktadır. Onarıcı adalet düşüncesinde, ceza adaleti bakımından suçtan ziyade ortaya çıkan bozulma ya da soruna odaklanılmaktadır. Buna göre suç işleme arzusuna yönelecek bir cezalandırma hakkı yanlış bir çıkış noktasıdır. Onarıcı ceza adaletinde sorunun tüm paydaşlarının sesi işitilir, suça dair değerlendirmeleri dikkate alınır ve suç sonrası mağdurun, failin ve toplumun tamiri için neler yapılacağı üzerinde durulur. ${ }^{89}$

Sosyal adaletin ceza adaleti üzerindeki etkileri ise üç farklı şekilde kendini göstermektedir. ${ }^{90}$ Bunlardan ilkine göre sosyal adalet, ceza adaletinin gerçekleştirilmesinde önemsizdir. Buna göre sosyal adaletin yöneldiği hedefler, ceza adaletinin hedefleri arasında yer almamaktadır. ${ }^{91}$ İkinci yaklaşıma göre sosyal adalet, ceza adaletini daha da kötü bir duruma sokmaktadır. Örneğin, Yeni Zelanda da olduğu gibi farklı kültürlerin taraf oldukları yasal problemlerin çözümünde sosyal adaletin etkin olması, yargısal anlamda adaleti eritici bir etkiye sebep olmaktadır. Buna göre sosyal adalet, kültürel çoğulculuğu ve bunlara alan açmayı öngörmektedir ki bu durum tek anlamlı ve istikrarlı batı tipi adalet anlayışıyla çelişmektedir. Bu durum elbette ki karmaşık ve zorlu bir reçete olarak, bir kültürden faili diğer bir kültürden mağduru belirlemek gibi bir sonuç doğurmaktadır. ${ }^{92}$ Son olarak karşımıza çıkan yaklaşım ise sosyal adaletin ceza adaletine olumlu katkılar sunacağını öngörmektedir. Buna göre sosyal adalet toplumun gerek mağdur gerekse faile

89 BRAITHWAITE, s.185-186.

$90 \mathrm{Bu}$ noktada adli yardım kurumunu da sosyal adaletin ceza adaletine olan etkileri arasında saymak mümkündür. "Adli yardım, mali gücü yetersiz olanların dava açma hakkından yoksun kalmaması için getirilmiş bir ilkedir. Mali olanakları yetersiz kişilerin dava harç ve masraflarından muaf tutulması ve kendisi için baro tarafindan ücretsiz avukat görevlendirilmesidir." "Adli yardım sadece özel hukuk ve idari davalar için söz konusudur. Ceza davalarında şüpheli ve mağdurlar açısından farklı usuller belirlenmiştir. Şüpheliler açısından, alt sınırı beş yıldan fazla hapis cezasını gerektiren bir suçun şüphelisi veya sağır ve dilsiz veya 18 yaşından küçük veya kendinizi savunamayacak derecede malul iseniz tarafınıza zorunlu müdafi (sanık avukatı) atanır. Müdafi seçebilecek durumda olmadığınızı beyan ettiğiniz takdirde isteminiz üzerine müdafi görevlendirilir. Mağdurlar açısından; 18 yaşını doldurmamış, sağır veya dilsiz ya da meramınızı ifade edemeyecek derecede malul olmanız durumunda zorunlu olarak, cinsel saldırı suçu ile alt sının 5 yıldan fazla hapis cezasını gerektiren bir suçun mağduru iseniz isteminiz hâlinde tarafınıza avukat görevlendirilir." Ayrıntılı bilgi için bkz. Adli Yardım Nedir? Mağdur Hakları Daire Başkanlığı, magdur. adalet.gov.tr/images/adli_yardim1.pdf (Erişim 30.09.2019)

91 BRAITHWAITE, s.186. Bu durumda aslında ekonomik olarak devlete yüklenen yük daha da artmaktadır. Buna göre devlet özellikle de hapishane gibi daha çok kamu binası yapmak durumunda kalacaktır. O’SHANE, s. 20.

92 BRAITHWAITE, s.187.

316 Ankara Hacı Bayram Veli Üniversitesi Hukuk Fakültesi Dergisi C. XXIII, Y. 2019, Sa. 4 
olan bakışını daha sağlıklı hale getirmektedir. ${ }^{93}$ Onarıcı adalette, okulu terk eden ya da uzaklaştırılan bir gencin okula dönmesi ya da işsiz bir faile iş bulunması gibi neticelere ulaşılabilmektedir ki bunlar sosyal adalet açısından olumlu adımlardır. Burada amaç iyi bir şeyler ortaya çıkartmaktansa zarardan kaçınmanın sağlanmasıdır. Örneğin işsizlik, suç oranlarının artmasında önemli bir etkiye sahiptir. ${ }^{94}$ Zira suçluların büyük oranda eğitimsiz ve işsiz kimseler oldukları dile getirilmektedir. ${ }^{95}$ Bununla birlikte rasyonalist bir ekonomi anlayışının anti-sosyal bir yapıda olduğuna ve bu anlayışın olduğu toplumlarda yasal yardımların düşüklügüne dikkat çekilerek ekonomi modeli ile suç artış oranlarında yükseliş yönünde bir korelasyon bulunduğu da ayrıca belirtilmektedir. ${ }^{96} \mathrm{Bu}$ noktada ABD'deki jüri sistemi üzerinde sosyal adalet bakımından yapılan bazı değerlendirmelere yer vermeyi faydalı görmekteyiz. Buna göre ABD Federal Anayasa siteminde, jürinin bireysel özgürlüklerin koruyucu bir fonksiyonu olduğu düşünülmektedir. Yine jüri sisteminin dayandığı teoriye göre hukuk, bir yandan jüri tarafindan somut hayat bilgisi ile, ama hukuk bilgisi olmaksızın ele alınırken, yargıç tarafından hayat bilgisi olmaksızın sadece soyut hukuki bilgi ile ele alınmaktadır. Bu durumda da jüri, delillerin hukuken nitelendirilmelerini göz ardı edebilmekte ve bu doğrultuda değerlendirmede bulunmaktadır. Jürinin, mahkemeyi tam ve doğru bir şekilde yönlendirememesi yargıcın kararını vermesini güçleştirmektedir. $\mathrm{Bu}$ kaçınılmaz sonuç, modern, endüstri atmosferinde canlılık kazanan hukukun bireyselleşmesi ve skolastikleşmesinin bir ürünü olarak görülmektedir. ${ }^{97}$

\subsection{Sosyal Adalet ve İdam Cezası}

Ceza adaleti bakımından ortaya çıkan tartışmalardan bir diğeri idam cezası hakkında gerçekleşmektedir. İdam cezasının uygulanması farklı yaklaşımlara ve politik tercihlere bağlı olarak gerçekleşebilmektedir. Bunlardan ilkine göre ağır suç işleyen herkese karşı idam cezasının uygulanması zorunlu tutulmalıdır. İkinci yani ihtiyari yaklaşıma göre ise idam cezası sadece bazı suçlar için söz konusu olabilmektedir. Son olarak idam cezasının hiçbir suç için uygulanmaması görüşü ileri sürülmektedir. Buna göre sosyal adalet, zorunlu ya da ihtiyari yaklaşımı doğrudan yasaklamadığı gibi bunları zorunlu

\footnotetext{
93 BRAITHWAITE, s.190.

94 BRAITHWAITE, s.191.

95 O'SHANE, s. 19.

96 O'SHANE, s. 19-20.

97 WEHLE, s.7.
} 
da kılmamaktadır. Bununla birlikte moral değerler dengesinin, zorunlu ya da ihtiyari yaklaşıma karşı olduğu ve belirgin bir şekilde idam cezasına karşı olduğu ifade edilmektedir. ${ }^{98} \mathrm{Bu}$ noktada tarafların hepsinin görüşlerini faydacı bir yaklaşımla sosyal adalet kavramına dayandırdıkları görülmektedir. ${ }^{99}$ Öte yandan yaşanan tartışmaların genel olarak tekerrür ve caydırıcılık kavramları ekseninde faydacı bir yaklaşıma dayandırıldığı söylenebilir. ${ }^{100}$ Buna göre huzurlu ve düzenli bir toplumda herkesin menfaati bulunmaktadır. Bu noktada suç ile mücadele bakımından, biraz klasik olsa da belirli gereksinimlerin karşılanıyor olması gerekmektedir. Zira toplumdaki tüm bireyler, açlıktan âzâde bir durumda bulunmalı, yeterli barınma imkanına sahip olmalı, yeterli ve erişilebilir sağlık hizmeti almalıdır. Bunlar sağlıklı bir kamu düzeni ve iyi bir yönetim bakımından temel esasalar olarak ele alınırlarsa, sonrasında işsizlik, enflasyon gibi ekonomik konuların değerlendirilmesine geçilebilir. ${ }^{101}$ Elbette ki sağlıklı ve sosyal adaletin yüksek düzeyde gerçekleştirilebildiği toplumlarda ceza adaletine duyulan ihtiyaç daha az seviyelerde olacaktır. $\mathrm{Bu}$ noktada idam cezasına yönelen ve yukarıda kısaca değinilen yaklaşımları biraz detaylandırmakta yarar görmekteyiz. Zira bu yaklaşımlar ceza adaletinin tayininde ve sosyal adaletin dengeye oturmasında önemli farklılıklar sergilemektedirler.

* İhtiyari yaklaşım; bu göre idam cezasının uygulanması farklılıklar arz edebilmektir. Örneğin ABD'de hangi suçlunun ağır ya da dehşet verici bir suç işlediği ve bu gerekçeyle idama mahkûm edileceği konusunda yargıçlara önemli bir takdir alanı bırakıldığı dile getirilmektedir. Bu nedenle bu yoğun ve geniş takdir yetkisi üzerinde iyi düşünülmelidir. Yine ihtiyari yaklaşımda suçun karşılığı olan cezanın yani misillemenin maksimize edilmesinde başarısızlıklar olabilmektedir. Ayrıca işlenen suçlara verilen cezalarda, eşitliği sağlama ya da standardı tutturma bakımından sıkıntılar doğabilmektedir. Cezanın belirliliğinin kestirilemeyecek olması da cezanın caydırıcılık etkisini oldukça zayıflatacaktır. ${ }^{102}$

* Zorunlu yaklaşım; bu yaklaşımı besleyen farklı görüş ve gerekçeler bulunmaktadır. Bunlardan birisi kısas, yani verilecek cezanın işlenen suçu birebir karşılayacak mahiyette olmasıdır. Buna göre eğer öç alma, yasal bir

\footnotetext{
98 BEDAU, s. 768.

99 BEDAU, s. 769.

${ }^{100}$ BEDAU, s. 769-770.

${ }^{101}$ O'SHANE, s.19.

102 BEDAU, s. 781.
} 
amaç olarak hedefe alınırsa idam cezası vasıtasıyla hem yargısal adalet hem de sosyal adalet bakımından amaca ulaşılmış olacağ 1 ifade edilmektedir. Yine hukuk önünde eşitlik, sosyal adalet bakımından vazgeçilmez bir ilkedir. Zorunlu yaklaşım, bu ilkeyi tam olarak tesis etmektedir, çünkü idam cezasını gerektiren tüm suçlarda bu ceza eşit olarak uygulanmaktadır. Son olarak idam cezasının sosyal savunmayı sağlayıcı bir etkisi olduğu ileri sürülmektedir. Buna göre idam cezası ile topluma karşı dehşet verici, ağır ihlaller, en ağır şekilde cezalandırılmakla birlikte sosyal savunma adına caydırıcı bir etki de meydana getirilmektedir. ${ }^{103}$

Terk yaklaşımı; idam cezasına tümden karşı olan bu yaklaşım, yaklaşımın, daha gerçekçi, insani ve adil olmasının yanı sıra toplumun tamamına yönelen bir ceza politikası anlayışını da yansıtmaktadır. Bu yaklaşıma göre hapis cezası, idam cezasına göre toplumsal iyi ve kötünün belirlenmesinde daha belirleyici bir konumdadır. Yine idam cezasının modern ve akılcı bir penolojik ${ }^{104}$ yaklaşım içerisinde rol alamayacağına vurgu yapılmaktadır. Buna göre toplum, cezai yaptırımlarda etkin olmanın yanı sıra insani olmanın da sorumluluğunu taşımalıdır. ${ }^{105}$ Yine modern kriminoloji ve penoloji, topluma yönelik saldırılarda belirlenen eski sorumluluk kriterlerinin ve cezalandırma biçimlerinin tümden yenilenmesi gerektiğine işaret etmektedir. ${ }^{106}$

\section{SOSYAL ADALET VE VERGI ADALETI}

Vergi sisteminde, bir yandan devletin geliri arttırılmak istenirken diğer yandan da vergi yükünün adil bir dağılımı hedeflenmektedir. Buna göre kaynakların dağılımında yüksek ve düşük gelir grupları bakımından ayarlama nasıl yapılıyorsa, vergi yükü bakımından da aynı yaklaşım tarzı belirlenmelidir. Bu noktada vergi gelirlerinin yeterli olabilmesi, vergi kesintileri yanı sıra kamu harcamaları üzerinde de durulmasını gerektirmektedir. Yine vergi sistemlerinde şeffaflı̆̆ın göz ardı edildiği, özellikle de tüketim vergilerinde gelir vergilerine nazaran bu durumun daha belirgin olduğu ileri sürülmektedir. ${ }^{107}$ Vergilendirme ile ilgili olarak ortaya çıkan bir diğer sorun ise eşitliktir. Bu kapsamda eşitlik, yatay ve dikey eşitlik olarak ele alınmaktadır. Dikey eşitlik bakımından

\footnotetext{
103 BEDAU, s. 770.

104 Penoloji, suçluların cezalandırması ve ardından topluma kazandırılması yöntemlerini araştıran bir suç bilimi dalıdır. www.tr.wikipedia.org/wiki/Penoloji (erişim 12.01.2019)

105 BEDAU, s. 795.

106 WEHLE, s.5.

107 STEWART, s. 159.
} 
vergilendirmede ölçü, verginin ödenebilme kabiliyetidir. Örneğin gelir vergisinde belirleme, bireyin gelirine göre yapılmaktadır. Buna göre yüksek gelirliye yüksek oranda, dar gelirliye ise diğerine göre daha az oranda bir vergi yükü yüklenecektir. Bu durumda da görüldüğü üzere bireylerin gelirleri açısından üstlenebilecekleri oranda bir vergi yükü ${ }^{108}$ getirilmek istenmektedir. Yatay eşitlikte ise bireyler bir derecelendirme yapılmadan standart bir vergilendirmeye tabi kılınmakta olup bu yöntem daha net ve anlaşılır bir sistem olarak görülmektedir. ${ }^{109}$ Öte yandan verginin tür olarak tekliği (monist) konusunda yapılan değerlendirmeler neticesinde, doğrudan verginin çeşitlilik arz edeceği, bu nedenle de "vergi tekliği" ifadesinin anlamsız olacağ ve fayda vermeyeceği düşünülmektedir. Zira burada "teklik" düşüncesi rasyonel tercih ve bireysel rekabetin ve mükemmel bir piyasa ekonomisinin temel ideolojileri üzerine dayandırılmaktadır. ${ }^{110}$ Öte yandan vergi sisteminin mali haklar yanı sıra doğrudan siyasi haklara yönelik sonuçları da olabilmektedir. Örneğin İngiltere'de "seçim vergisi" olarak adlandırılan bir vergi türünün, seçme hakkına yönelik, doğrudan ve olumsuz bir etkisi söz konusu olmaktadır. Zira bu vergi yükümlülüğünden kaçmak isteyen seçmenler, seçmen kütüklerine kayıt olmaktan kaçınmaktadırlar. Görüldüğü üzere burada sistem, vergi adaletinin çok ötesinde, seçme hakkının kullanımını baskılayan ve caydırıcı etkiye neden olan bir faktör olarak karşımıza çıkmaktadır. ${ }^{111}$

\section{SONUÇ}

Sosyal adalet toplum içerisinde birey gruplarının ya da toplumun belirli kesimlerinin arasında sosyal denge ve uyumun sağlanması bakımından önemli bir kavramdır. Buna göre sosyal adaletin tesisi sayesinde hukuken uyuşmazlık çıkabilme ihtimali azaltılabilmektedir. Bu bakımdan sosyal adaletin gerçekleşmesi sorunu kaynağında halletme adına atılan bir hamle olarak değerlendirilebilir. Bu nedenle insan hakları bakımından parlamentolara yüklenen yükümlülükler sosyal adaletin tesisinde faklı bir boyutu gündeme getirmektedir. Buna göre sosyal dengesizliklere politik

${ }^{108} 1982$ Anayasasında da yer alan düzenleme bu doğrultudadır. Anayasa madde 73/1-2 şu şekildedir; "(1) Herkes, kamu giderlerini karşılamak üzere, mali gücüne göre, vergi ödemekle yükümlüdür. (2) Vergi yükünün adaletli ve dengeli dağılımı, maliye politikasının sosyal amacidir."

109 STEWART, s. 159.

110 STEWART, s.159.

${ }^{111}$ THOMPSON, Phil, Social Justice under Thatcher, Sri Lanka Journal of International Law, 1998, s.281. 
çözümlerin bulunamaması karşısında yargının bu görevi üstlenmesi söz konusu olabilecektir. Örneğin, vergi adaleti bakımından toplum kesimleri arasındaki dengesizlik, aynı zamanda anayasa hukuku açısından da yargısal bir sorun haline gelebilecektir. Buna karşın adaletin tesisi, daha yasama sürecinin başlangıcında ortaya çıkmaktadır. Buna göre yasamanın toplum kesimleri arasındaki dengeyi göz ardı etmesi ya da sağlayamaması halinde sosyal alandaki adaletsizlik yarg1 önüne taşınabilmektedir. Bu noktada ortaya çıkan dengesizlik, özünde yasamanın politik tercihlerinde düşülen hataların neticesinde ortaya çıkmakta olup süreç bazı insan hakları ihlalleri ile de neticelenebilmektedir. Bu manada özellikle çevre hakkı, çocuk hakları, cinsiyet ayrımcılığı, sağlık hakkı gibi alanlarda yasamanın tasarrufları anayasal güvence altında bulunan bu hakları ihlal edici mahiyette olabilmektedir. Anayasa yargısında denetlenebilen ve anayasaya aykırılık teşkil eden böylesi yasal düzenlemeler iptal edilmek suretiyle yargısal adaletin yanı sıra sosyal adalet de tesis edilebilmektedir. $\mathrm{Bu}$ nedenle anayasa mahkemeleri yargisal adaletin yanı sıra yasamanın hatasını telafi edecek mahiyette sosyal adaletin dahi dağıtıcısı konumuna gelebilmektedir. Sonuç olarak görevi gereği politik bir tercih ya da öngörüden uzak, sadece hukukilik denetimi yapan bir yarg1 mercii olarak anayasa mahkemeleri aynı zamanda sosyal adaleti de sağlayıcı bir fonksiyon icra etmektedir.

\section{KAYNAKÇA}

BARRY Brian: Why Social Justice Matters, 1. Bask1, Polity Press, Cambridge, 2005.

BEDAU, Hugo Adam, The Death Penalty: Social Policy and Social Justice, Arizona State Law Journal, 1977.

BRAITHWAITE, John: Restorative Justice and Social Justice, Saskatchewan Law Review, C.63.

CAMPBELL, Tom: Can the Law Deliver Social Justice, University of Western Sydney Law Review, C.5.

COLLINS Chuck, YESKEL Felice: Economic Apartheid in America: A 
Primer on Economic Inequality and Insecurity, 1.Bask1, The New Press, New York, 2000.

DIAS, Maria Clara: Affirmative Action and Social Justice, Connecticut Law Review, C.36.

EWING Keith: Just Words and Social Justice, Review of Constitutional Studies, C.5, Sa.1.

FOLEY, Edward B: Social Justice and Child Poverty, Ohio State Law Journal, C.57.

FORTIN, Ernest L: Natural Law and Social Justice, American Journal Jurisprudence, C.30

FRASER, Nancy: From Redistribution to Recognition?: Dilemmas of Justice in a "Postsocialist" Age, New Left Review, C.212, Sa.1, July-August.

GOTTLIEB, Henry M: Legal Rights and Social Justice, University of Detroit Law Journal, C.2.

HAZARD, Geoffrey C. Jr: Social Justice through Civil Justice, University of Chicago Law Review, C.36.

HUNTER, Nan D: Lawyering for Social Justice, New York University Law Review, C.72, November.

KALSEM, Kristin, WILLIAMS, Verna L: Social Justice Feminism, UCLA Women's Law Jorrnal, C.18.

MACRORY, R: Environmental Standards, Legitimacy and Social Justice, Acta Juridica,1999.

MINSON Jeffrey: Second Principles of Social Justice, Law Context: A SocioLegal Journal, C.10.

NOVAK, Michael: What is Social Justice, Capital University Law Review, C.21.

O'SHANE, Pat: Social Justice for Aborigines, Alternative Law Journal, C.19, Sa. 1, February.

PERLSTADT, Harry: Court Decisions, Social Problems and Social Justice, ALSA Forum, (American Legal Studies Assoc.), C.8, Sa.2.

POSNER, Eric A: SUNSTEIN Cass R., Global Warming and Social Justice, Regulation, C.31, Spring. 
POUND, Roscoe: Social Justice and Legal Justice, Centeral Law. Journal, C.75.

ROBERTS, Dorothy E: Sources of Commitment to Social Justice, Roger Williams University Law Review, C.4.

RODES Robert E. Jr: Social Justice and Liberation, Notre Dame Law Review, C.71.

ROGOVIN, V: Social Justice and Improving Distribution Relations, Soviet Law and Government, C.25, Summer.

SANDOVAL Clara: Transitional Justice and Social Change, SUR International Journal on Human Rights, C.20.

STEWART, Miranda: Reforming Tax for Social Justice, Alternative Law Journal,C.23,Sa. 4.

SOLAS John: What Kind of Social Justice Does Social Work Seek, International Social Work, C.51. Sa.6.

SYTNICHENKO, Liudmyla: Otfried Hoffe's Theory of Social Justice, Polish Political Science Yearbook, C.44.

THOMPSON, Phil: Social Justice under Thatcher, Sri Lanka Journal of International Law, 1998.

WEHLE, Louis B: Social Justice and Legal Education, American Law Review, C.51.

WELlMan, Carl: Social Justice and Human Rights, Persona \& Derecho, C.17.

WILEY, Lindsay F: Health Law as Social Justice, Cornell Journal of Law And Public Policy, C.24.

YATES Al, BARTLEY Anne: Progressive Thinking: A Synthesis of American Progressive Values, Beliefs and Positions, American Values Project, Denver, 2012, www.tr.scribd.com/document/131793272/ Progressive-Thinking (erişim: 16.01.2019)

www.tr.wikipedia.org/wiki/Penoloji (erişim: 12.01.2019)

www.seslisozluk.net/ableism-nedir-ne-demek/ (erişim: 16.01.2019)

www.seslisozluk.net/nativism-nedir-ne-demek/ (erişim: 16.01.2019) 
Sosyal Adalet Kavramının Bazı Temel Haklar İle Ceza ve Vergi Adaletine Etkileri

324 Ankara Hacı Bayram Veli Üniversitesi Hukuk Fakültesi Dergisi C. XXIII, Y. 2019, Sa. 4 